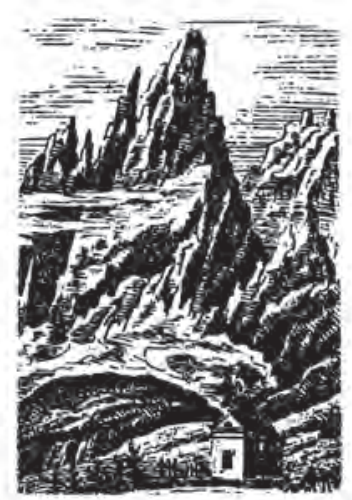

Małgorzata Łoboz

ORCID: 0000-0002-0705-8219

Uniwersytet Wrocławski

malgorzata.loboz@uwr.edu.pl

https://doi.org/10.19195/2084-4107.13.15

\title{
„Tańczą góralczyki” i śpiewają. Idealizacja górali podhalańskich w wybranych realizacjach literacko- -muzycznych XIX i XX wieku
}

Słowa-klucze: folklor podhalański, Tatry w literaturze, Tatry w muzyce, Wincenty Pol, Stanisław Moniuszko, Ignacy Jan Paderewski, Karol Szymanowski

Keywords: Podhale folklore, Tatras in literature, Tatras in music, Wincenty Pol, Stanisław Moniuszko, Ignacy Jan Paderewski, Karol Szymanowski

\section{Dancing and singing highlanders: Idealisation of highlanders from the Podhale region in literary-musical works from the 19th and 20th centuries}

\section{Summary}

The article is an attempt to describe various manifestations of highland folklore in selected literary-musical works, including fragment XV of Wincenty Pol's 1847 poetic cycle Obrazy z po- 
dróży [Images from a Journey] to which music was composed by Adam Münchheimer. It could even be said that if Pol expressed in the poem an uncritical idealisation of highland folklore (it is worth noting the visual beauty of the protagonists of this vitalistic dance), Münchheimer took this idealisation even further. Writing the song to be performed by a baritone and male choir, he deprived it of the primeval austerity and uncontrollable dynamics of highlanders' dance. An important item in the Polish operatic repertoire is Stanisław Moniuszko's Halka (premiered in 1858), composed to a libretto by Włodzimierz Wolski. Hugely important to the narrative of the work is the fact that Halka is a highland girl and that the action takes place in the village of Odrowąż (probably on the border with Orawa). Scholars agree that there is no real highland folklore in Halka (Moniuszko had never been to the Tatras!); instead, we have an uncritical idealisation of highlanders manifested in a clear axiological division into positive and negative protagonists.

In the case of the most popular ballet idealising highland folklore, i.e. Karol Szymanowski's Harnasie (composed between 1823 and 1831 to a script by Jerzy and Helena Rytard), its stage productions took on various forms, from a faithful reconstruction of highland folklore, to stylisation, from modest sets to colourful spectacle, from a vividly portrayed dramatic conflict to a subtle narrative in which dance became the main means of expression.

Co robią górale w sytuacji lirycznej wiersza Wincentego Pola (zatytułowanego Tańcza góralczyki)? Tańczą, a oprócz tego że tańczą — przygrywają do tańca (być może weselnego, bo z przodu tańczy drużba). Chłopcy tańczą, kapela gra, dziewczęta śpiewają. Można odnieść wrażenie, że to poetycka ilustracja ludowych „malowanek na szkle”. Jest to niewątpliwie rodzajowa scenka z życia obyczajowego górali podhalańskich — w Obrazach z podróży, cyklu poetyckim nie najwyższej miary, lecz bardzo spójnym (w porównaniu do cyklu $Z$ podróży po burzy) zbiorze Wincentego Pola, powstałym między 1834 a 1843 rokiem (opublikowanym w $1847 \mathrm{roku}$ ), największą rolę odgrywa zbiorowy portret ludu góralskiego. Jak twierdził monografista poety, Maurycy Mann: „nie krajobrazy górskie, nie opisy zajmują tu pierwsze miejsce, ale lud tatrzański, jego życie i poezja; wspaniała przyroda służy tylko za tło, na którym autor ukazuje niezmiernie sympatyczne typy mieszkańców hal i dolin"1.

Rzeczywiście pejzaż tatrzański i ontologia gór są tam jedynie tłem eksponowanej tradycji kulturowej, idealizującej góralszczyznę. Można odnieść wrażenie, że pierwszorzędnym celem autora była właśnie owa idealizacja. Należy się przy tym zgodzić z Jackiem Kolbuszewskim, sugerującym, że cykl pozbawiony jest stylizacji folklorystycznych, a fraza „Tańczą góralczyki” oraz nieliczne nawiązania do tradycyjnych źródeł kulturowych świadczą raczej o pseudofolklorystycznym ujęciu ${ }^{2}$. Nie ulega jednak wątpliwości, że dla podmiotu lirycznego swoistym antidotum wobec zmagań z przeciwnościami losu staje się kontakt z folklorem góralskim. W opinii Kolbuszewskiego „w tym zbiorze wierszy Pola ma początek ta bezkrytyczna idealizacja góralszczyzny, której apogeum, z jego długotrwałymi i społecznymi skutkami, przypadło na okres Młodej Polski"3. Wincentego

1 M. Mann, Wincenty Pol. Studium biograficzno-krytyczne, t. 1, Lwów 1904, s. 338.

2 Por. J. Kolbuszewski, Tatry w twórczości literackiej Wincentego Pola, [w:] Obrazy natury i kultura. Studia o Wincentym Polu, red. M. Łoboz, Wrocław 2015, s. 55.

3 Ibidem. 
Pola, poetę skoncentrowanego dotychczas na realistycznej deskrypcji natury (co potwierdzają Obrazy z życia i natury), do głębszej refleksji prowokuje zachwyt nad witalistyczną siłą, tkwiącą w ukształtowanych przez region górski cechach osobowościowych mieszkańców.

I gdyby nie lud, co dumne te czoła,

I te przepaści oplątał ścieżkami [...]

Widok ogromu byłby bez pociechy,

Bo duch pojmuje tylko ducha tchnienie ${ }^{4}$

— konstatuje sceptycznie narrator. Pol poświadcza w tym poetyckim stwierdzeniu stale obecną w historii literatury hipotezę, że dla romantyków lud z jego folklorem stał się interpretacyjnym kluczem do czytania w księdze natury. Na tejże podstawie Jan Gwalbert Pawlikowski w rozprawce $Z$ dziejów poezji tatrzańskiej (1906) sformułował stwierdzenie, że „kto chce poznać duszę Tatr, musi spojrzeć na nie oczyma zamieszkującego ludu"5, zakładając konieczność traktowania problematyki Tatr w kontekście równorzędnego interpretowania zarówno fenomenu górskiej przyrody, jak i folkloru góralskiego. „Zstępowanie” do duszy i charakteru narodowego Polaków przez świadome odkrywanie pierwotnej historii narodu było istotnym elementem zamierzonego programu sztuki, którego jednym z wyznaczników było odtwarzanie rodzimego krajobrazu ${ }^{6}$. Pola natomiast, skoncentrowanego na bezpośredniej deskrypcji natury, do głębszej refleksji prowokuje zachwyt nad życiodajną siłą, tkwiącą w ukształtowanych przez górską naturę cechach osobowościowych górali.

Z tego między innymi powodu poeta w Obrazach z podróży sięgnął po wybrane podania ludowe i przywołał chociażby legendę o cudownym stole i obrazie Najświętszej Panny Ludźmierskiej, opowiadania góralskie o Bolesławie Chrobrym, który czekanem rozciął góry i stworzył koryto Dunajca, o czarodziejskiej księdze Twardowskiego, którą biskupi krakowscy przykuli łańcuchami, aby się bezbożna nauka po świecie nie szerzyła, opowieść o bohaterze góralskim, górniku Grzeli (wspomnianym w przytoczonym wierszu), zwanym Królem na Magurze. Poza tym (zainspirowany przez znany mu rękopis $O$ mieszkańcach gór tatrzańskich Ludwika Kamieńskiego) swój poetycki cykl próbował urozmaicić „etnograficznymi” obrazkami góralskiej codzienności. Wspomina towarzyskie „posiady” u Kasi Sobczakówny, wiele uczucia wkłada w opowiadanie o rannym wygnańcu, który w chacie górala, przeżywszy rok, pokochał córkę swego gazdy, która cierpiała, gdy ten zmuszony był uciec na Orawę.

W ostatnim wierszu wyraził przekonanie, że dusza ludu góralskiego jest czystsza i szlachetniejsza od duszy mieszkańców nizin, do których woła dumnie:

${ }^{4}$ W. Pol, Obrazy z podróży, [w:] Dzieła Wincentego Pola wierszem i proza, t. 9, Lwów 1878, s. 205.

5 Cyt. za: J. Kolbuszewski, Tatry w literaturze polskiej 1805-1939, Kraków 1982, s. 8.

${ }^{6}$ Por. A. Kowalczykowa, Pejzaż romantyczny, Kraków 1982, s. 99. 
Was nie rozjaśni ten świat swym uśmiechem,

Ani was natchną góry swym oddechem,

Ani was górskie wody nie obmyją,

Ani w was prawdy ludu nie ożyją ${ }^{7}$.

Ów romantyczny wędrowiec zadaje sobie fundamentalne pytania egzystencjalne, na które drobna rybka moralistka z górskiego potoku odpowiada mu z perswazją dydaktyczną:

Gdy ci ni szczytów, ani głębi dostać,

Kiedy nie zdołasz, biedne chłopię, sprostać

Temu, co proste - i temu, co wielkie,

To zniknij iskrą i zlej się w kropelkę...

Widok ogromu byłby bez pociechy ${ }^{8}$.

Radzi mu więc zrezygnować ze szlachetnych, wzniosłych indywidualnych przeżyć. Te antyromantyczne dyrektywy składają się na wyznanie wiary filistra w spokojną, małą stabilizację jako przeciwwagę romantycznego dążenia do wzniosłości i metafizykę gór. Bezkrytyczna idealizacja (skutkująca w wielu wypadkach przerysowanym kiczem) skłania do szerszych perswazji interpretacyjnych, bardziej uniwersalnych w swej treści.

Mimo że w górach przyjemnie spędza czas, ów antyromantyczny bohater liryczny, który nie napił się „,szalonego ziela”, ma świadomość, że zostać tam nie może. Krótkie chwile egzystencji „wśród ludu, co w słońcu pływał” pochłonęły go całą duszą i jest przeświadczony, że takich „czystych” i twardych ludzi jak bohaterowie góralscy musi szukać aż do śmierci, więc choć mgła zakryła przestrzeń krajobrazu, jego umysł jest zainteresowany tylko tym, co znajduje się poza mgłą: „A pod tem morzem jak wiele narodu. I jakie tam ziemie rozbite”. Dlatego tęskni za innymi widokami; pragnie zobaczyć kościół Mariacki, usłyszeć dzwony wawelskie, oglądać Kraków i przestrzeń rozciągającą się za miastem, chce objąć myślą i wzrokiem wszystkie lądy i krajobrazy, wyżyny, równiny rozpięte na obszarze „od morza do morza”. W innym wierszu na przeszkodzie stoją mgły „wewnętrznego życia” natury, jedynie hardy charakter góralski jest w stanie ten zamglony krajobraz pokonać. W tej „przesłodzonej” stylizacji na folklor góralski poeta kreuje nowego bohatera literatury romantycznej, przedstawiciela ludowych dążeń patriotycznych ${ }^{10}$, czyli górala Grzelę (który w obrazku piętnastym tańczy na czele orszaku) - organizatora strajku górników, ,na całe góry największego zuchwalca", który nie chciał poddać się uciskowi i przystał do zbójników. Pochwała stylu życia i myślenia „wolnych Górali” sąsiaduje z fragmentami głoszącymi „pojednanie z rzeczywistością”; jednocześnie Pol przejawiał krytyczny stosunek

\footnotetext{
7 W. Pol, op. cit., s. 242.

8 Ibidem, s. 205.

9 Ibidem, s. 231.

10 Por. M. Janion, Wstęp, [w:] Wincenty Pol. Wybór poezji, Wrocław 1963, s. 65, BN I 180.
} 
do patetycznego, romantycznego buntu przeciwko rzeczywistości, do apologii samotnej wielkości profetycznego bohatera ${ }^{11}$. Ludowa stylizacja na folklor ma tu więc głęboko przemyślaną intencję autorską, a popularyzacja utworu w formie skocznego mazura (asymilującego elementy tradycyjnego tańca góralskiego) potwierdza autentyzm estetycznych impresji.

Na tle rozbudowanego i pojemnego w sensie filozoficznym cyklu poetyckiego piętnasty obrazek przedstawia drobny wycinek codziennej obyczajowości góralskiej. Obrazuje niedzielne popołudnie w karczmie, w której odbywają się tradycyjne góralskie „,posiady” z tańcem i śpiewem. Do śpiewnika narodowego tekst ten wszedł dzięki Adamowi Münchheimerowi, który spopularyzował go w formie pieśni (znanej pod tytułem Góralczyki), układając do niego melodię, przeznaczoną do wykonywania przez baryton solo i chór męski ${ }^{12}$. Osoba kompozytora, który należał do ówczesnej elity artystycznej Warszawy, niewątpliwie nobilitowała tekst cenionego w drugiej połowie XIX wieku poety. Utwór można zatem uznać za znakomity przykład duetu artystycznego dwóch wybitnych luminarzy kultury. Pol związany z Galicją — znany jako poeta i geograf, zasłużony uczestnik powstania listopadowego, podróżopisarz i krajoznawca-podróżnik, popularyzator wycieczek naukowych, zbieracz folkloru, żarliwy propagator piękna ziemi ojczystej i kultury regionalnej, pionier polskiej etnografii — znał Tatry z autopsji i zetknął się z kulturą folkloru góralskiego (jak wcześniej wspomniałam — czytał Kamieńskiego, współpracował i rywalizował poniekąd z Ludwikiem Zejsznerem, któremu Obrazy z podróży zadedykował). Münchheimer, wnuk Abrahama, założyciela fabryki guzików, wyrobów pieczątkarskich i metalowych (przybysza ze Śląska do Warszawy), uczeń skrzypków J. Hornziela i A. Freyera w Warszawie, a później A.B. Marxa w Berlinie w 1850 roku, został zatrudniony jako skrzypek orkiestry, w 1858 roku został dyrektorem muzycznym; w latach 1864-1891 był dyrygentem, a od 1872 roku, po śmierci Stanisława Moniuszki, objął stanowisko dyrektora Teatru Wielkiego w Warszawie. Był jednym ze współzałożycieli Warszawskiego Towarzystwa Muzycznego, w którego ramach założył orkiestrę. Komponował opery wystawione w Warszawie (Otton tucznik, 1864; Stradiota, 1876; Mazepa, 1885; Mściciel, 1897), jako kierownik baletu miał w swym dorobku również inscenizację baletową (Figle szatana, 1870), zrealizowaną we współpracy z Moniuszką, z którym współpracował w Warszawskim Towarzystwie Muzycznym (notabene w 1872 roku Münchheimer zorganizował pogrzeb Moniuszki, komponując specjalnie na tę uroczystość Marsz żałobny, oparty na motywach utworów zmarłego; warto też poczynić dygresję, że to właśnie Münchheimer w 1860 roku opracował uwspółcześnioną wersję linii melodycznej Bogurodzicy, do dzisiejszych czasów wykonywanej w jego transkrypcji).

11 Ibidem, s. 68.

12 Z. Rondomańska, Poezja kompozytorów polskich w twórczości kompozytorów polskich i muzyków-amatorów, [w:] Ponad hafem wicher wyje... Studia o Wincentym Polu, red. N. Kasparek, A. Korytko, Olsztyn 2011, s. 93. 
Pieśń znana pod tytułem Tańcza góralczyki jest dość skrótową, lecz dynamiczną ilustracją wyprawy po przeżycia estetyczne, eksponującą naturalny urok kultury ludowej:

Tańczą góralczyki,

Chłopaki jak smyki,

Kobzarz im przygrywa,

A dzieweczka śpiewa.

Jak wcześniej wspomniano, z idealizacji gór wyrastała filozofia życia uczestników tego zdarzenia folklorystycznego, jakim jest taniec w karczmie. Warto dodać, że w tym literacko-muzycznym duecie łączą się trzy istotne przesłania: ekspozycja estetycznego piękna ludu góralskiego w portrecie folklorystycznym, gloryfikacja dynamiki uosabiającej siłę moralną oraz psychiczne cechy osobowościowe ludu góralskiego, a także popularyzacja kultury góralskiej w formie muzyki regionalnej. Trzeba tutaj przyznać, że druga połowa XIX wieku przyniosła znaczący rozwój. O ile w latach trzydziestych XIX wieku podhalański folklor muzyczny był zupełnie niedoceniony, bo niezrozumiały, o czym świadczą stwierdzenia Seweryna Goszczyńskiego, w rodzaju:

Śpiewy ich są posępne, wysilone, przeciągłe, wyobrażają niejako hukanie z jego rozgłosem po górach. Jest w nim pewna jednotonność, dlatego uczenie się ich jest trudne; udało mi się jeden zrozumieć i zdaje mi się, że już wszystko umiem [...]. Muzyka tańca jest całkiem oryginalna, niepodobna do żadnej muzyki tego rodzaju; jest niby jednotonna, ale tak rozmaita, tak jakaś nieskończona, że mieszkający nawet od dawna między góralami wygrać jej nie mogą ${ }^{13}$,

tak późniejsze dokonania w dziedzinie zbieractwa źródeł wokalistyki na Podhalu znacząco te poglądy przeobraziły. Wspomnieć tu należy publikację Pieśni ludu polskiego w Galicji (przez Żegotę Paulego w 1838 roku), lecz nade wszystko pierwszą antologię pieśni góralskich, zatytułowaną Pieśni ludu Podhalan, czyli górali Tatrowych polskich, którą w 1845 roku opublikował Ludwik Zejszner. Równolegle z Zejsznerem działał ksiądz Eugeniusz Janota. Jego zbiór pieśni podhalańskich opublikował Adolf Chybiński dopiero w 1923 roku. Atutem pracy Janoty są nutowe zapisy pieśni, aczkolwiek jego notacja nie była wolna od błędów; podobnie teka Oskara Kolberga Góry i Pogórze. Następnie wymienić trzeba Jana Kleczyńskiego, który był profesjonalnym muzykiem, jako autora Melodii zakopiańskich i podhalskich (1888), czyli nutowego zapisu 86 melodii i rozmaitych wariantów linii melodycznych góralskich, w większości w transkrypcji fortepianowej. Dla niniejszych rozważań nad idealizacją góralszczyzny wymowny jest następujący komentarz Józefa Kantora, autora szkicu Pieśń i muzyka ludowa Orawy, Podhala i Spisza (1919-1920): „Za mało jest być kompozytorem

13 S. Goszczyński, Dziennik podróży do Tatrów, Warszawa 1853, s. 144. 
i wykonawcą, nawet mistrzowskim, symfonii Beethovena czy Chopina preludii, nokturnów itp.; tu konieczna jest rzeczą posiąść zdolność wczuwania się w stany duszy podhalańskiej, pokochać ją wraz z jej muzyką"14. To był kluczowy temat rozważań niezmiernie bogatej publicystyki na przełomie XIX i XX wieku: emocjonalizm folkloru góralskiego i konieczność znajomości specyfiki regionalnej Tatr dla pełnego jej zrozumienia.

W drugiej połowie XIX wieku można zatem wyodrębnić dwie przeciwstawne tendencje interpretacyjne wobec góralszczyzny, będące podstawą późniejszej działalności kompozytorskiej ${ }^{15}$. Wedle pierwszej koncepcji, reprezentowanej przez Zygmunta Noskowskiego, należało swobodnie traktować ludowy, źródłowy autentyk, a przez stosowanie techniki „wygładzania” melodii ludowej oraz symetrycznego jej rozłożenia $w$ ramach struktury utworu melodie te nawiązują do klasycyzmu i pieśni osiemnastowiecznych oraz tych z początku XIX wieku. Adam Münchheimer prezentował stanowisko wręcz przeciwne - uważał, że autentyczne melodie ludowe powinny zostać zachowane i funkcjonować równolegle z wyrazistą, uwspółcześnioną strukturą harmoniczną oraz tekstem słownym, który dla kompozytora był równie istotny co wartość muzyczna. W pieśniach lirycznych tego okresu stosunek muzyki do tekstu opiera się na dwóch różnych założeniach: 1) supremacji melodyki jako najważniejszego środka wyrazu muzycznego; 2) równorzędnej funkcji wszystkich elementów muzycznych w przekazywaniu ekspresji tekstu ${ }^{16}$. Münchheimer zrealizował te założenia wobec tekstu Pola. Ubierając go w rytm mazura, popularnego tańca ludowego, szeroko praktykowanego w kulturze folkloru nie tylko podhalańskiego, upodobnił go do charakterystycznej melodii góralskiej, operującej niewielką rozpiętością skali (w tym przypadku septymą z obniżonym dźwiękiem e), zaopatrując $\mathrm{w}$ tonację majorową (B-dur; melodie góralskie nierzadko budowane są na skali lidyjskiej z obniżonym siódmym stopniem) i rytm synkopowany, z silniejszymi akcentami na nutach o krótszej wartości. Adolf Chybiński, analizując 20 wybranych melodii góralskich, doceniał ich specyfikę; twierdził jednak, że muzyka góralska nie ma żadnych związków z muzyką innych regionów Polski. Dostrzegał natomiast jej związki z muzyką słowacką, rumuńską, węgierską, chorwacką. Motyw tańczących góralczyków zapewne zainspirował znany już wówczas w latach osiemdziesiątych XIX wieku słynny Marsz Chałubińskiego autorstwa Jana Kleczyńskiego (czyli zinstrumentalizowaną wersję wiersza Tetmajera Hej, idem w las!, który z kolei powstał pod wpływem tematu „Tańcowali zbójnicy w murowanej piwnicy”. To też była pieśń zanotowana przez Kleczyńskiego i opublikowana w „Pamiętniku Tatrzańskim” w 1888 roku). Warianty tej melodii można znaleźć w twórczości Beli Bartoka i w piątym Tańcu węgierskim Brahmsa. Miał więc Münchheimer znakomite wzorce i trzeba przyznać, że choć Kleczyński go przewyższał - stworzył

14 Cyt. za: L. Długołęcka-Pinkwart, M. Pinkwart, Muzyka i Tatry, Warszawa 1992, s. 16.

15 Por. Kultura muzyczna Warszawy drugiej połowy XIX w., red. A. Spóz, Warszawa 1980, s. 213.

16 Ibidem. 
udaną stylizację na folklor góralski. Wybór tekstu o przewadze wątków epickich, gdzie komunikatywna funkcja słowa wysuwa się na plan pierwszy, nie jest u tego kompozytora przypadkowy.

Można wręcz zasugerować, że skoro Pol wyraził w tym wierszu bezkrytyczną idealizację góralszczyzny (warto też zwrócić uwagę na wizualne piękno bohaterów tego witalistycznego tańca), Münchheimer tę idealizację jeszcze mocniej przeidealizował. Przeznaczając pieśń do wykonania barytonowi i chórowi męskiemu, pozbawił go pierwotnej surowości i nieokiełznanej dynamiki góralskiego tańca.

Zanim podobny typ idealizacji bohaterów góralskich przejdzie do literatury i sztuki Młodej Polski, należy zatrzymać się na kolejnym ogniwie tej ewolucji, a mianowicie na idealizacji góralszczyzny w polskiej operze. Wiadomo, że proweniencja gatunku operowego zakłada skłonność do hiperboliki i przekazu emfatycznych, egzaltowanych emocji. Pominę tu Krakowiaków i górali Bogusławskiego, a pozostając w kręgu literatury romantycznej, chcę się zatrzymać na libretcie Włodzimierza Wolskiego do Halki Stanisława Moniuszki, której premiera obyła się w 1858 roku. W całej tej historii fabularnej ogromne znaczenie ma fakt, że Halka jest góralką, a akcja dramatu rozgrywa się w miejscowości Odrowąż (prawdopodobnie na granicy z Orawą). Swe uczucia do ukochanego Janusza (szlachcica z nizin, który poślubił piękną Zofię Stolnikównę, czego Halka nie była świadoma) wyraża poprzez identyfikację z regionem, z syndromem ,naszej ziemi”:

Prawda, już mnie nie porzucisz!

Wrócisz w nasze góry, wrócisz,

Sokole mój!

Nad rzeczułką ja usiędę,

I tak tęskno czekać będę,

Aż przylecisz wraz.

Wtedy będziem zawsze społem,

Zawsze z tobą, z mym sokołem.

Chyba śmierć rozłączy nas! ${ }^{17}$

Janusz natomiast pięknie ją oszukuje, powtarzając ów ważny komunikat:

Tak, ja cię już nie porzucę,

Wrócę w nasze góry, wrócę,

Aniele $^{18}$.

Jak zgodnie twierdzą interpretatorzy Moniuszki, w muzyce Halki nie ma wpływów podhalańskich, choć rytm dwućwierciowy nieco przypomina taniec góralski, ale należy się dopatrywać raczej wpływów Krakowiaków i górali w wersji Józefa Stefaniego. Do stworzenia Halki Moniuszko długo się przygotowywał. Spodobał mu się dwuaktowy rękopis libretta, pierwotnie zatytułowanego Halszka, aczkolwiek uważał tekst za zbyt krótki. Według anegdoty w 1847 roku, zdeprymo-

17 W. Wolski, Halka, Warszawa 1910, s. 18.

18 Ibidem. 
wany zbyt długim oczekiwaniem na poprawkę tekstu, Moniuszko zamknął Wolskiego u siebie na całą dobę na klucz i oświadczył, że go nie wypuści, dopóki nie otrzyma pełnego czteroaktowego libretta. Poza tym w „Bibliotece Warszawskiej” przeczytał prace Zejsznera na temat muzyki ludu podhalańskiego i pod wpływem tej lektury skomponował Tańce góralskie z zamiarem włączenia ich do Halki (notabene wspomniane Tańce Moniuszki śpiewała Maria Kalergis przy akompaniamencie samego Liszta!). Góralszczyzny w Halce zatem nie ma (ale też Moniuszko nigdy w Tatrach nie był!) — jest za to jej bezkrytyczna idealizacja, ujawniająca się w wyrazistym podziale aksjologicznym na bohaterów negatywnych (niewierny i kłamliwy Janusz) oraz szlachetnych (zakochany Jontek, skrzywdzona Halka i solidarni z jej nieszczęściem górale) oraz w nastrojowej kreacji pejzażu górskiego, zaakcentowanego w tekście libretta (na przykład w słynnej arii Jontka, zaczynającej się od incipitu: „Szumią jodły na gór szczycie/Szumią sobie w dal”"19 , w której młody góral wspomina, jak przynosił Halce z gór „najwonniejsze kwiaty”20), jak i w projekcie scenograficznym. W didaskaliach sceny finałowej zaznaczono, że górale siedzieli na skałach i z wysokości szczytów nieruchomo i niemo obserwowali samobójstwo bohaterki w górskim potoku.

Ten motyw niewątpliwie kojarzy się z librettem innego melodramatu, o którym już przed laty pisałam, a mianowicie Manru Paderewskiego (do libretta Alfreda Nossiga), czyli przeróbce znanej powieści J.I. Kraszewskiego Chata za wsią. Tutaj skały Mnicha i Mięguszowieckich Szczytów stały się świadkami tragedii o potężnym ładunku nieujarzmionych emocji i depresyjnych stanów szaleństwa w prawdziwie romantycznej tonacji. Na dnie Morskiego Oka zginęło troje bohaterów tej tragedii. W projekcie scenograficznym wyeksponowany został skromny wygląd chatki górskiej oraz ponury pejzaż czarnego, wyłaniającego się z mgły Giewontu; w akcie trzecim uwagę zwraca mroczna sceneria górskiego jeziora i szczytów oświetlanych blaskiem księżyca. Nawet jeżeli pejzaż wydaje się kiczowaty, to ta przerysowana otoczka patetycznej rozpaczy wpisuje się w charakterystyczne dla opery stereotypy patosu i wzniosłości. Ponieważ balet był najistotniejszym i najbardziej spektakularnym elementem inscenizacji grand operá, to w dziele Paderewskiego zauważalna jedna scena baletowa przypomina taniec góralski, mimo że brakuje jej tempa.

Za sprawą Paderewskiego doszliśmy w tych rozważaniach do Młodej Polski i autora najpopularniejszego obrazu baletowego idealizującego góralszczyznę. Chodzi oczywiście o Harnasie Karola Szymanowskiego, który pisał je między 1923 a 1931 rokiem, wedle scenariusza opracowanego przez Jerzego i Helenę Rytardów. Zanim jednak dzieło zostało ukończone, spisany scenariusz zaginął, dlatego przed premierą w Pradze Szymanowski prosił Leona Schillera o pomoc w opracowaniu trzeciego obrazu. Prapremiera praska w 1933 roku zapoczątkowała karierę tego oryginalnego dzieła, nobilitowanego poprzez premierę paryską w 1936 roku. Szczegółowa analiza treści baletowych to temat na kolejny, osobny referat. Mimo

19 Ibidem, s. 36.

20 Ibidem, s. 37. 
że — jak pisał Szymanowski — „sztuka narodowa jako postulat jest nieporozumieniem", to w tej różnorodności stylów, indywidualnych języków muzycznych kompozytorów tworzących w XX wieku nadal istnieje wyraźny ciąg kontynuujący tradycje dziewiętnastowiecznych „szkół narodowych”. Zapewne dlatego sceniczne realizacje Harnasiów przybierały rozmaite i zróżnicowane w formie inscenizacje — od wiernej rekonstrukcji góralskiego folkloru do jego artystycznej stylizacji, od skromnej faktury scenograficznej do barwnego efektu, od mocno zarysowanego konfliktu dramatycznego do subtelnej narracji, w której głównym środkiem wyrazu stał się taniec. Podobną mitologizację góralszczyzny zastosowała Zofia Stryjeńska w rysunkowym cyklu Tańców ludowych (1927), które mogły być inspiracją dla autorów scenariusza, o którym Jarosław Iwaszkiewicz napisał, że ,jest daleko idącym uogólnieniem, mitologizowaniem góralszczyzny, pasowaniem obyczajowości pewnego regionu polskiego na "prapolszczyznę« — jak jakąś "prasłowiańszczyzną" wydawało się być Święto wiosny Strawińskiego"21.

W epilogu scenariusza wyczytać można skromną konkluzję baletu: „Na hali rozlega się śpiew górala. Harnaś i Młoda razem szczęśliwi w górach”. Jak widać, taniec i śpiew jako wyraz bezkrytycznej idealizacji gór i góralszczyzny zapisały swe „długie trwanie” w różnorakich tekstach kultury polskiej.

\section{Bibliografia}

Długołęcka-Pinkwart L., Pinkwart M., Muzyka i Tatry, Warszawa 1992.

Goszczyński S., Dziennik podróży do Tatrów, Warszawa 1853.

Janion M., Wstęp, [w:] Wincenty Pol. Wybór poezji, Wrocław 1963, BN I 180.

Kolbuszewski J., Tatry w literaturze polskiej 1805-1939, Kraków 1982.

Kolbuszewski J., Tatry w twórczości literackiej Wincentego Pola, [w:] Obrazy natury i kultura. Studia o Wincentym Polu, red. M. Łoboz, Wrocław 2015.

Kowalczykowa A., Pejzaż romantyczny, Kraków 1982.

Kultura muzyczna Warszawy drugiej połowy XIX w., red. A. Spóz, Warszawa 1980.

Mandragora. Mity. Harnasie, red. B. Winnicka, program inscenizacji w Teatrze Wielkim w Warszawie, Warszawa 1982.

Mann M., Wincenty Pol. Studium biograficzno-krytyczne, t. 1, Lwów 1904.

Obrazy natury i kultura. Studia o Wincentym Polu, red. M. Łoboz, Wrocław 2015.

Pol W., Dzieła Wincentego Pola wierszem i proza, t. 9, Lwów 1878.

Rondomańska Z., Poezja kompozytorów polskich w twórczości kompozytorów polskich i muzyków-amatorów, [w:] Ponad hafem wicher wyje... Studia o Wincentym Polu, red. N. Kasparek, A. Korytko, Olsztyn 2011.

Wolski W., Halka, Warszawa 1910.

${ }^{21}$ Cyt. za: Mandragora. Mity. Harnasie, red. B. Winnicka, program inscenizacji w Teatrze Wielkim w Warszawie, Warszawa 1982. 